\title{
Insecurity and Business Performance: The Operation Management Challenge in Ikot Ekpene, Akwa Ibom State of Nigeria
}

\author{
Opusunju Michael Isaac ${ }^{1}$, Akyuz Murat ${ }^{2}$, Ibrahim Yusuf Ohida ${ }^{1}$ \\ ${ }^{1}$ Department of Business Administration, Nasarawa State University, Keffi, Nigeria \\ ${ }^{2}$ Nile University Of Nigeria, Abuja, Nigeria
}

Email address:

Opusunjumike@gmail.com (O.M. Isaac), murat.akyuz@nileuniversity.edu.ng (A. Murat), yusufohida@yahoo.com (I. Y. Ohida)

\section{To cite this article:}

Opusunju Michael Isaac, Akyuz Murat, Ibrahim Yusuf Ohida. Insecurity and Business Performance: The Operation Management Challenge in Ikot Ekpene, Akwa Ibom State of Nigeria. American Journal of Environmental and Resource Economics. Vol. 4, No. 4, 2019 , pp. 132-138. doi: $10.11648 /$ j.ajere.20190404.13

Received: September 3, 2019; Accepted: October 8, 2019; Published: October 31, 2019

\begin{abstract}
The study examines insecurity and business performance: the operation management challenge in Ikot Ekpene, Akwa Ibom State using small business owners. The study used survey research design using structural questionnaire administered to the respondents who are small business owners in Ikot Ekpene. The study used regression analysis and correlation as statistical tools to analyse the data. The study found that there is a positive significant effect of insecurity on small business performance and also there is a significant relationship between operation management challenge and small business performance. The study suggested that Small business should try to adopt more principles of operation management in dealing with insecurity situation in Ikot Ekpene, Akwa Ibom State. They should monitored external and internal business environment because it posse challenge to operation management among the owners of small business in Ikot Ekpene, Akwa Ibom State.
\end{abstract}

Keywords: Insecurity, Business Performance, Business Growth, Operation Management

\section{Introduction}

Insecurity in Nigeria has affected the activities of business in Nigeria especially Akwa Ibom State (Ikot Ekpene) where shops and offices are closed by 5.30PM due to theft, Army Robbery, Kidnapping, Assassination and Fraud as well as killing. These insecurities causes operation management to stop production or utilization of available resources such as material, men, machine etc which invariably affect the performance of selected small business in Akwa Ibom State (Ikot Ekpene Local Government Area). The performance small business in Ikot Ekepene Local Government are is very low since shops and business centers closed early and some of the shops or small centers experienced army robbery activities after the they have closed. Insecurity activates affected the production department and as well as designed and controlled process of production and redesigning business operations in the production of goods or service in order to enhance the performance of small business in Ikot
Ekpene, Akwa Ibom State.

Over the last four years in Akwa Ibom State and most recently this year, Ikot Ekpene Local Area have experience activities of theft, Army Robbery, Kidnapping, Assassination and Fraud as well as killing among youths of the Universities who reside in the area. Government of Akwa Ibom state have employed armies and police to stop this activities that result to business short-down or temporary closure by $5 \mathrm{PM}$ in order to design and control production activities and increase performance of small business in Ikot Ekpene Local Area. Yet there is frequently activities of theft, Army Robbery, Kidnapping, Assassination and Fraud as well as killing and this reduced the production activities as well as performance of small business in Ikot Ekpene, Akwa Ibom State.

Extent literature such as $[1,3]$ determined if the insecurity had effect on the Small Business operations using Yobe State and Nigeria. None of these studied used Ikot Ekpene in Akwa Ibom State using a period of 2018. This study fills the research gap by examining the effect of insecurity on the 
performance of small business viewing it in operation management perspective in Ikot Ekpene, Akwa Ibom State of Nigeria.

The objective of this study is to examine the effect of insecurity on the performance of small business in Ikot Ekpene, Akwa Ibom State of Nigeria. The specify objectives are to evaluate the effect of insecurity on the growth of small business in Ikot Ekpene, Akwa Ibom State of Nigeria.

The scope of this study is restricted to the effect of insecurity on the performance of small business viewing it in operation management perspective in Ikot Ekpene, Akwa Ibom State of Nigeria. The period of study is 5 years from 2014 to 2018. The period is chosen because the activities of theft, Army Robbery, Kidnapping, Assassination and Fraud as well as killing and these activities affect operation management in the area such design and controlling production activities.

The hypothesis is stated in a null form:

$\mathrm{H}_{01}$ : There is no significant effect of insecurity on business growth among small business owners in Ikot Ekpene, Akwa Ibom State.

\section{Concept of Insecurity}

The Concept of insecurity connotes different meanings such as: absence of safety; danger; hazard; uncertainty; lack of protection, and lack of safety. The term insecurity is a state of fear or anxiety due to absence or lack of protection [8]. Insecurity is from two perspectives. Firstly, insecurity is the state of being open or subject to danger or threat of danger, where danger is the condition of being susceptible to harm or injury. Secondly insecurity is the state of being exposed to risk or anxiety, where anxiety is a vague unpleasant emotion that is experienced in anticipation of some misfortune [3].

Insecurity is continually on the increase thereby engulfing all the inhabitants of Nigeria as the government faces insurmountable pressure to guarantee the security of lives and properties of its citizens [5]. The insecurity in Nigeria ranges from kidnapping and activities of terrorist and human trafficking in the South-South and the South-East, high level of arms robbery in the South-West and the activities of political vanguards, Islamic extremist in the North. In Yobe state, the incidences of the insecurity that occurred are multifaceted and multidimensional. Activities of political vanguards, killings by hired assassins by political and business opponents and the Islamic extremism by Boko Haram group are a few cases in point. It is however important to be noted that all these forms of insecurity are induced by politicians $[5,14,4]$. They also maintained that it is no longer a sect of Islamic militants, but has the support of discontented politicians and their paid gangsters.

\subsection{Concept of Business Performance}

Operational performance is focused on improving efficiency and effective systems which are reliable and can ensure excellent which exceed customer expectations. To get such sustainable operational results, operations strategy is developed which supports the organization in ensuring the key operational aspects of the firm are met; cost reduction, speed of product development and production, flexibility of the production system and quality assurance for the product [20]. However, [19] argued that most organisational performance can be grouped into one of the following six general categories. However, certain organizations normally develop their own categories as appropriate depending on the organization's mission: a) Effectiveness: A process characteristic indicating the degree to which the process output (work product) conforms to requirements of the organisation; b) Efficiency: A process characteristic indicating the degree to which the process produces the required output at minimum resource cost; c) Quality: The degree to which a product or service meets customer requirements and expectations; d) Timeliness: Measures whether a unit of work was done correctly and on time. However, the criteria must be established to define what constitutes timeliness for a given unit of work. The criterion is usually based on customer requirements; e) Productivity: The value added by the process divided by the value of the labour and capital consumed; and f) Safety: Measures the overall health of the organization and the working environment of its employee.

\subsection{Business Growth}

Growth of a business is a complex concept and takes two broad forms namely; organic (expanding by increasing overall customer base, output per customer and new sales) and inorganic (expansion through mergers, acquisitions or takeovers). Choice of the method of growth depends on the type of business, resources available, time, money and equity sweat the owner is ready to spend. Strategies for growth and implication management includes penetration strategies, market development strategies, product development strategies and diversification [18].

Growth is an important phenomenon in small enterprises. In fact, their survival essentially depends on their power to participate in the market with other big companies. Growth decreases the possibility of closing small businesses [17]. Also, growth is the product of an internal process in the development of an enterprise and an increase in quality and/or expansion. Growth is defined as a change in size during a determined time span [11].

A company's growth is essentially the result of expansion of demands for products or services [13]. It first results in a growth in sales and consequently in investments in additional production factors to adapt itself to new demands [13]. However, Entrepreneurs' ideas on growth and listed the following: increase in sales, increase in the number of employees, increase in profit, increase in assets, increase in the firm's value and internal development. Internal development comprises development of competences, organizational practices in efficiency and the establishment of professional sales process. This was the most important index for entrepreneurs that participated in the research. However, increase in the number of employees was not 
necessarily considered a sign of growth [2].

Growth may be related to new markets, especially in the case of technology firms, with reference to diversification. They are also of the opinion that growth may occur alternatively as an integration of part of the value chain, a sort of vertical growth, or when a firm introduces itself within a market not related to the technology in which it works, which would be a non-related diversification [10]. Another type of growth may be related to the combination of market-product by entrance into the market [10]. Also, growth is a geographical expansion, increase in the number of branches, inclusion of new markets and clients, increase in the number of products and services, fusions and acquisitions [9].

\subsection{Control Variable and Operation Management Challenge}

Operations management is challenging as a branch of study because it employs highly technical and highly specialized language and approaches [12]. In addition, another challenge emerges in the context of business activities and business environment, especially as both context and environment change to alter the effectiveness of operations techniques and processes for managers and businesses [12]. Moreover, the levels of technical and problem solving or conceptual skills required in understanding and applying the tools and techniques of operations management create the most significant challenge for business owners and managers. Business managers and owners must be able to delve into the deeper sides or aspects of processes that create value by understanding activity flow and interrelationships between productive inputs or variables (the factors of production) and how external and internal environmental factors affect how effectively and efficiently these can be combined to produce goods and create services [12].

Figure 1: Conceptual Framework.

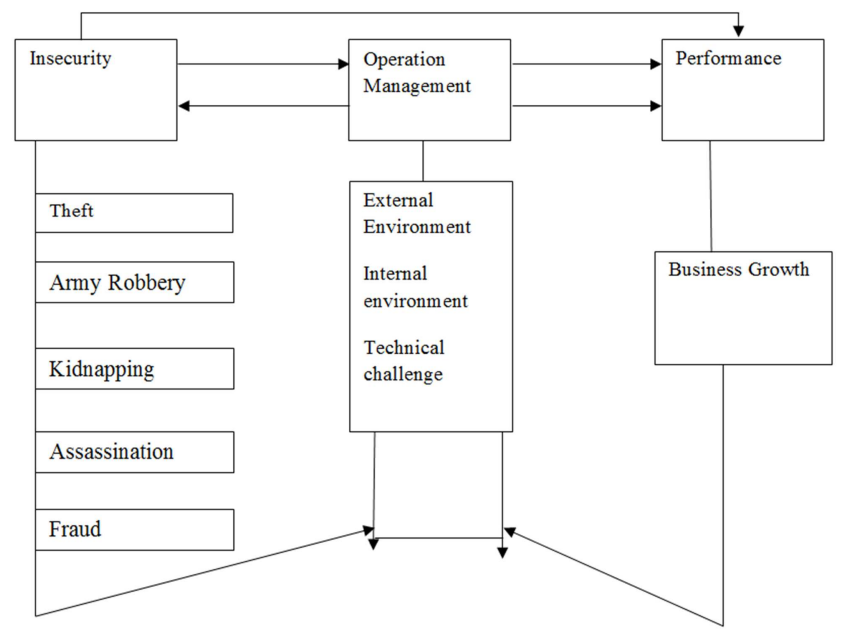

Figure 1. Model of Insecurity and performance in the context of operation Management.

\subsection{Empirical Studies}

Previous study examined the insecurity situation in Nigeria and its implications for business investment, operations and sustainable development. The evaluation of the level and dimension of insecurity which was based on secondary data and observations among authors in different places, zones and walks of life as expressed in their comments, as well as, on concrete evidences of insecurity incidence in different parts of Nigeria, indicated that the insecurity challenge in the country is enormous and complex and would continue to be, if the situation remains unabated. They therefore emphasized the need to evolve a safe business environment that allows $f$ or effective business activities and a sustainable development process [3].

A similar study was conducted to determine if the insecurity had effect on the Small Business operations in Yobe State. Additionally another objective of the study was to evaluate the consequences of insecurity or its negative impact on socio-economic development of the state. To achieve these objectives, the researcher adopted survey method. Questionnaire was administered to 200 Small Business owners randomly selected from Damaturu and Potiskum Local Government Areas in Yobe State. Two research questions and two Hypotheses were formulated to guide the study. Mean and standard deviations were used in analysing the research questions, while the hypotheses were tested using the t-test at 0.05 significant levels. The result indicated that the two means from Tables 1 and 3 are greater than'2' (midpoint value); thus, answering 'yes' to the two research questions. In the same vein, Hol and Ho2 were accepted because the critical t-values forboth groups are greater than $\mathrm{t}$-value obtain from the analysis on tables 2 and 4; thus, the respondents unanimously agreed that the insecurity seriously affected Small Business operations and negatively impacted the socio-economic development of the State [1].

Study was empirically investigating the impact of insecurity on foreign direct investment (FDI) covering the period of 2003 to 2012. The study employed Least Square technique (OLS) to analyze the secondary data collected from Central Bank of Nigeria Statistical bulletin of various issues. Vote on security and defense (VSD) was used as a proxy for insecurity. The paper reveals a negative relationship between Foreign Direct Investment (FDI) and insecurity [16].

\subsection{Theoretical Framework}

Over the years three distinct views have evolved about conflict in organizations. These include: traditional view, behavioural or contemporary view, and interactionist view. The traditional view (dominant from the late nineteenth century until the mid-1940s) assumes that conflict is bad, always has a negative impact, and leads to declines in performance as the level of conflict increases [6]. Conflict must therefore always be avoided. Although that approach worked sometimes, it was not generally effective; when they 
are suppressed, the root causes cannot be identified, and the potentially positive aspects of conflict cannot emerge. The behavioural or contemporary view, also known as the human relations view, emerged in the late 1940s and held sway through the 1970s. It argues that conflict is natural and inevitable in all organizations and that it may have either a positive or a negative effect, depending on how the conflict is handled [6]. Performance may increase with conflict, but only up to a certain level, and then decline if conflict is allowed to increase further or is left unresolved. This approach advocates acceptance of insecurity and rationalizes its existence. The interactionist view assumes that conflict is necessary to increase performance. While the behavioural approach accepts conflict, the interactionist view encourages conflict based on the belief that a harmonious, peaceful, tranquil, too-cooperative project organization is likely to become static, apathetic, stagnant, and unable to respond to change and innovation [6]. This approach encourages managers to maintain an appropriate level of conflict-enough to keep organizations self-critical, viable, creative, and innovative [6].

\section{Methodology}

The study adopted survey research design and this is because the data needed in this study requires the use of questionnaire administered to the respondents who are the owners in small business in Ikot Ekpene, Akwa Ibom State, Nigeria. The population of this study includes all the small business registered in Ikot Ekpene which is made of 11 wards. However, the population of this study is 4212 owners in small business in Ikot Ekpene according to pilot study conducted by the researchers since there was not document capturing the total number of small business in Ikot Ekpene and this was reduced using Taro Yamane formula as stated below:

$$
\mathrm{n}=\mathrm{N} / 1+\mathrm{N}(\mathrm{e})^{2}
$$

Where $\mathrm{N}$ is the population size

$\mathrm{e}$ is the margin error (assume 5\%)

$1=$ constant $=$

$\mathrm{e}=0.05$

$\mathrm{n}=4212 / 1+4212(0.05)^{2}$

$\mathrm{n}=4212 / 1+4212(0.0025)$

$\mathrm{n}=4212 / 1+10.53$

$\mathrm{n}=4212 / 11.53$

$\mathrm{n}=365$

The sample size of this study was 365 and the questionnaire was designed in five point likert scale and was administered randomly to the owners of small business in Ikot Ekpene across the 11 wards. The study used regression and correlation as well as mean in analysing the data with the aid of econometric view 9.00. Regression is used to determine the cause and effect relationship variables while correlation was used to determine the degree of the relationship between variables. The study tested for t-statistic and f-statistic, p-statistic, coefficient of determination, Durbin Watson and standard error. The f-statistic indicates the overall significance of the independent variables on the dependent variable. The mathematical model of this study was $\mathrm{Y}=\mathrm{a}+\mathrm{bx}$ where $\mathrm{y}$ is the dependent variable (performance of small business) and $a$ is the intercept or constant, $\mathrm{b}$ is the coefficient and $\mathrm{x}$ is the independent variable (insecurity). However, due to error that may occur since we may not be efficient, the introduction of statistical model was set in this study. Therefore statistical model of regression was stated below:

$$
\mathrm{BG}=\alpha+\beta_{1} \mathrm{INS}+\beta_{2} \mathrm{OPMC}+\mu
$$

Where:-

$\mathrm{BG}=$ Business Growth

INS=Insecurity

$\mathrm{OPMC}=$ Operation management challenge

$\alpha=$ Intercept,

$\beta=$ Coefficient

$\mu=$ error term

Correlation model

$\mathrm{r}=\mathrm{n} \sum \mathrm{xy}-\sum \mathrm{x} \sum \mathrm{y}$

$$
\sqrt{\left.\left\{\left(\mathrm{n} \sum \mathrm{x} 2\right)-\left(\sum \mathrm{x}\right) 2\left(\mathrm{n} \sum \mathrm{y} 2\right)-\left(\sum \mathrm{y}\right) 2\right)\right\}}
$$

Where:

$\mathrm{r}=$ Correlation Coefficient

$\mathrm{x}=$ proxies for independent variable

$\mathrm{y}=$ proxies for dependent Variable

$\mathrm{n}=$ number of observations

The questionnaire collected was tested to ensure that the questionnaires are properly answered and result indicated as:

Table 1. Reliability test.

\begin{tabular}{lll}
\hline Variables & Number of items & Cronbach's Alpha \\
\hline Business growth & 5 & 0.96 \\
Insecurity & 3 & 0.84 \\
Operation management challenge & 3 & 0.81 \\
\hline
\end{tabular}

Source: researcher's computation (2018)

However, the Alpha values are reliable.

\section{Data Analysis and Discussion}

Table 2. Characteristics of the respondents.

\begin{tabular}{lllll}
\hline S/NO & Characteristics & Respondents' Category & Frequency & Percent \\
\hline & & Male & 201 & 55.06 \\
1. & Sex & Female & 164 & 44.94 \\
& & Total & 365 & 100.00 \\
\hline
\end{tabular}




\begin{tabular}{lllll}
\hline S/NO & Characteristics & Respondents' Category & Frequency & Percent \\
\hline & & $18-30$ years & 78 & 21.36 \\
& & $31-40$ Years & 84 & 23.01 \\
2. & Age & 41-50Years & 117 & 32.05 \\
& & 51 years and above & 86 & 23.01 \\
& & Total & 365 & 100.00 \\
& Educational & OND/NCE & 89 & 24.38 \\
& & HND/B. Sc & 100 & 27.39 \\
3. & Q. Sc/PGD & 76 & 20.82 \\
& Qualification & Basic Education & 100 & 27.39 \\
& & Total & 365 & 100.00 \\
\hline
\end{tabular}

Source: Survey Data, 2018

The respondents' sex as displayed in table 2 above for small business Ikot Ekpene, Akwa Ibom State indicates that males are 201 respondents representing $(55.06 \%)$ who participated in the exercise and females were 164 respondents re presenting (44.94). The table shows that majority of the owners have different age ranging from 18 to 30 years had 78 respondents representing $(21.36 \%), 31$ to 40 years had 84 respondents representing (23.03\%), 41 to 50 years had 117 respondents representing (32.05\%) and 51 years and above had 86 respondents representing (23.01\%). The respondents that were educated had 89 respondents presenting (24.38\%) who possessed OND/NCE, 100 respondents representing $(27.65 \%)$ who possessed HND/B. Sc, 76 respondents representing (20.82\%) who possessed M. Sc/PGD and 100 respondents representing $(27.65 \%)$ who had basic education.

Table 3. Descriptive statistics.

\begin{tabular}{llll}
\hline & BG & INS & PGM \\
\hline Mean & 3.027292 & 2.912728 & 2.295313 \\
Median & 3.000100 & 3.000000 & 3.000000 \\
Maximum & 5.000000 & 5.000000 & 5.000000 \\
Minimum & 1.000000 & 1.000000 & 1.000000 \\
Std. Dev. & 1.118012 & 1.239810 & 1.051359 \\
Skewness & -0.056788 & -0.055843 & 0.241333 \\
Kurtosis & 2.187346 & 1.286465 & 2.361824 \\
Jarque-Bera & 11.77290 & 11.63593 & 10.01058 \\
Probability & 0.014578 & 0.001244 & 0.016570 \\
Sum & 1174.000 & 1130.000 & 1015.000 \\
Sum Sq. Dev. & 478.7316 & 518.7396 & 421.3516 \\
Observations & 365 & 365 & 365 \\
\hline
\end{tabular}

The descriptive statistics shows that the average scores for BG, INS and PGM are 3.02, 2.91, and 2.29 respectively and the Jargue-Bera probabilities in the respective variables shows that the data are not normally distributed since the probability is less than $5 \%$. However, the data set were screen and the probabilities were greater than $5 \%$ which implies that data set are normally distributed and the screened data were used to analysed the work.

Table 4. Correlation Matrix.

\begin{tabular}{llll}
\hline & BG & INS & PGMC \\
\hline BG & 1 & & \\
INS & 0.505935 & 1 & 1 \\
PGM & 0.279771 & 0.326463 & 1 \\
\hline
\end{tabular}

Econometric view, 9.00, 2018

Table 4 indicates that there is a positive association between the dependent variable and independent variables in the study. This implies that there is a positive association between performance of small business and insecurity. Also, there is a positive association between Small business performance and operation management challenge and there is positive association between insecurity and operation management challenge in Ikot Ekpene, Akwa Ibom State of Nigeria.

Table 5. Regression Result.

\begin{tabular}{lllll}
\hline Dependent Variable: BG & & & \\
\hline Method: Least Squares & & & & \\
\hline Date: 21/09/18 Time: 15: 42 & & & & Prob. \\
\hline Sample: $\mathbf{1 ~ 3 6 5}$ & & & t-Statistic & 0.0000 \\
\hline Included obser0vations: $\mathbf{3 6 5}$ & Coefficient & Std. Error & 12.55169 & 0.0389 \\
\hline Variable & 0.614857 & 0.041089 & 3.072279 & \\
\hline C & 0.106881 & 0.051577 & & \\
INS & & &
\end{tabular}




\begin{tabular}{|c|c|c|c|c|}
\hline \multicolumn{5}{|c|}{ Dependent Variable: BG } \\
\hline \multicolumn{5}{|c|}{ Method: Least Squares } \\
\hline \multicolumn{5}{|c|}{ Date: 21/09/18 Time: 15: 42} \\
\hline \multicolumn{5}{|c|}{ Sample: 1365} \\
\hline \multicolumn{5}{|c|}{ Included obser0vations: 365} \\
\hline Variable & Coefficient & Std. Error & t-Statistic & Prob. \\
\hline PMGC & 0.632850 & 0.041018 & 11.17934 & 0.0100 \\
\hline R-squared & 0.707429 & Mean dependent var & & 2.811708 \\
\hline Adjusted R-squared & 0.616698 & S. D. dependent var & & 1.394918 \\
\hline S. E. of regression & 0.416082 & Akaike info criterion & & 1.141913 \\
\hline Sum squared resid & 68.18752 & Schwarz criterion & & 1.183116 \\
\hline Log likelihood & -215.2127 & Hannan-Quinn criter. & & 1.151311 \\
\hline F-statistic & 1241.613 & Durbin-Watson stat & & 1.082528 \\
\hline Prob (F-statistic) & 0.000000 & & & \\
\hline
\end{tabular}

Econometric view, 9.00, 2018

Decision rule: $5 \%$

The analysis indicates that the coefficients for insecurity and operation management challenge are significant in enhancing small business performance in terms of business growth in Ikot Ekpene, Akwa Ibom State of Nigeria. The pvalue and t-statistic values of the independent variables are significant at probability value of 0.000 for two variables. However, the f-statistic value of 1241.613 is significant at $p$ statistic value of 0.00 , it indicates that the model is a good fit and a Durbin Watson value of 1.08 which provides evidence of existence of linear relationship between (insecurity and operation management challenge) and Small business performance in terms of business growth in Ikot Ekepen, Akwa Ibom State. The $\mathrm{R}^{2}=0.61$ indicates that only $61 \%$ of insecurity and operation management challenge embarked upon by small business in Ikot Ekepene, Akwa Ibom State can be explain by performance but $39 \%$ can explained by other factors not noted in the regression model which is refer to as error term. Therefore we accept the alternative hypothesis that there is a significant relationship between insecurity and small business performance and also there is a significant relationship between operation management challenge and small business performance.

From the analysis, there is a positive association between the dependent variable and independent variables in the study. This implies that there is a positive association between performance of small business and insecurity. Also, there is a positive association between Small business performance and operation management challenge and there is positive association between insecurity and operation management challenge in Ikot Ekpene, Akwa Ibom State of Nigeria. The study also found that there is there is a significant relationship between insecurity and small business performance and also there is a significant relationship between operation management challenge and small business performance. The finding is in tandem with the findings of Abbas and Sani (2016) who found that there is a significant relationship between insecurity and performance. The study also is in line with the traditional view (dominant from the late nineteenth century until the mid-1940s) assumes that conflict/insecurity is bad, always has a negative impact, and leads to declines in performance as the level of conflict increases.

\section{Conclusions and Recommendations}

The study concluded that there is a positive association between the dependent variable and independent variables in the study. This implies that there is a positive association between performance of small business and insecurity. Also, there is a positive association between Small business performance and operation management challenge and there is positive association between insecurity and operation management challenge in Ikot Ekpene, Akwa Ibom State of Nigeria. The study also found that there is there is a positive significant effect relationship between insecurity and small business performance and also there is a significant relationship between operation management challenge and small business performance. The study suggested that Small business should try to adopt more principles of operation management in dealing with insecurity situation in Ikot Ekpene, Akwa Ibom State. They should monitored external and internal business environment because it posse challenge to operation management among the owners of small business in Ikot Ekpene, Akwa Ibom State.

\section{References}

[1] Abbas, S. M. S. \& Sani, M. (2016). Affect of Insurgency on Operations of Small and Medium Business Enterprises: A Study on Impact Assessment in Nigeria. Indian Journal Of Applied Research, 6 (9).

[2] Achtenhagen, L., Naldi, L., \& Melin, L. (2010). "Business growth": do practitioners and scholar really talk about the same thing? Entrepreneurship Theory and Practice, 34 (3), 289-316.

[3] Achumba, I. C., Ighomereho, O. S. \& Akpor-Robaro, M. O. M. (2013). Security Challenges in Nigeria and the Implications for Business Activities and Sustainable Development. Journal of Economics and Sustainable Development, 4 (2) 67-89.

[4] Adagba, O., Ugwu, S. C. and Eme, O. I. (2012). Activities of Boko Haram and Insecurity Question in Nigeria, Arabian Journal of Business and Management Review, Vol. 1, No.9, 77-99. 
[5] Adegbami, A. (2013): Insecurity: A threat to Human Existence and Economic Development in Nigeria.

[6] Ajike, E. O., Akinlabi, B. H., Magaji, N. \& Sonubi, A. O. (2015). Effect Of Conflict Management On The Performance Of Financial Service Organisation In Nigeria: An Empirical Study Of Access Bank Plc. International Journal of Economics, Commerce and Management, I (2).

[7] Belal, A. R. and Owen, D. L. (2007). The Views of Corporate Managers on the Current State of, and Future Prospects for, Social Reporting in Bangladesh: An Engagement-Based Study ${ }^{6}$. Accounting, Auditing Accountability, 20 (3): p 472494.

[8] Beland, D. (2005). The P olitic al Construction of Collective Insecurity: From Moral Panic to Blame Avoidance and Organized Irresponsibility. Center for Eur opean Studies, Working Paper Series 126.

[9] Brush, C. G., Ceru, D. J., \& Blackburn, R. (2009). Pathways to entrepreneurial growth: the influence of management, marketing, and money. Business Horizons, 52 (5), 481-491.

[10] Davidsson, P., \& Honig, B. (2010). The role of social and human capital among nascent entrepreneurs. Journal of Business Venturing, 18 (3), 301-331.

[11] Dobbs, M. \& Hamilton, R. (2007). Small business growth: Recent evidence and new directions. Int. J. Entrepreneurial Behav. Res., 13: 296-322.

[12] Donovan, A. M. (2014). The Challenges of Operations Management for Business Managers. International Journal of Operations and Logistics Management, 3 (1) 16-29.
[13] Janssen, O. (2009) / The joint impact of perceived influence and supervisor supportiveness on employee innovative behavior. Journal of Occupational and Organizational Psychology, Vol. 78 No. 4, pp. 573-578.

[14] Lister, A. (2012). Impact of insecurity on business performance. International Journal of human resource Management, 3 (2) 44-56.

[15] Penrose, E. (2006). A Teoria do Crescimento da Firma (T. Szmrecsányi, Trad.), Editora da UNICAMP, Campinas (English original published in 1959).

[16] Owolabi, A. \& Ayenakin, O. O. (2015). Insecurity And Foreign Direct Investment In Nigeria. International Journal of Sustainable Development \& World Policy, 4 (4): 56-68.

[17] Rauch, A. \& Rijskik, S. A. (2013). The effects of general and specific human capital on long-term growth and failure of newly founded businesses. Entrepreneurship Theory and Practice, 22 (11) 33-47.

[18] Robert, J. (2009). The success and failure of performance measurement initiatives. Perceptions of participating managers. International Journal of Operations and Production Management.

[19] Russell, P. \& Russell, O. (2011). Performance Indicators in Organization. Journal of Business Finance, 2 (3).

[20] Wiley, J. (2010). Analysis of performance in Service Industry. Journal of Business Administration, 2 (2) 10-22. 